\title{
Sustaining Vocabulary Acquisition through Computer Game: A Case Study
}

\author{
Nadzrah Abu Bakar ${ }^{1} \&$ Elaheh Nosratirad ${ }^{1}$ \\ ${ }^{1}$ Faculty of Social Sciences and Humanities, Universiti Kebangsaan Malaysia, Malaysia \\ Correspondence: Nadzrah Abu Bakar, School of Language Studies and Linguistics, Faculty of Social Sciences \\ and Humanities, Universiti Kebangsaan Malaysia, 43600 Kajang, Selangor, Malaysia. E-mail: nadz@ukm.my
}

\author{
Received: February 4, 2013 Accepted: February 27, 2013 Online Published: April 27, 2013 \\ doi:10.5539/ass.v9n5p235 URL: http://dx.doi.org/10.5539/ass.v9n5p235
}

\begin{abstract}
Learning vocabulary is not easy and it may be very frustrating to some learners. Many approaches have been taken to attract learners to learn new vocabulary. The aim of this case study is to explore how a computer game can be adapted as a learning tool to sustain adult vocabulary learning independently. This study used the existing SIM 3 game as a selected platform to investigate the vocabulary learning among ESL adult learners in an independent learning environment. Three adult ESL learners from different backgrounds participated in this study. Learners were examined on how they learned vocabulary and the learning experiences that helped them to gain new knowledge of English vocabulary while playing the game. A combination of mixed-data methods, including playing session observations, semi-structured interviews, a self-report checklist, pre- and post-tests and vocabulary lists, were used to collect extensive data. The findings show that computer games can be beneficial in sustaining language learning, especially in providing space to learn independently. With enough practice and consistent playing, along with the right objective of using it, a computer game can be utilized as a tool for independent learning to learn new vocabulary.
\end{abstract}

Keywords: computer games, ESL / EFL, independent learning, language learning, vocabulary

\section{Introduction}

The ability of ESL learners to use English almost like native speakers is the aim of every learner. The importance of developing English language skills among ESL adult learners, especially to gain English knowledge in order to communicate well, is a challenge. According to Barcoft (2004), the ability to use language fluently and grammatically correctly is directly related to knowledge of vocabulary that is built up over time and depends, on exposure to large amounts of language. Learners who have more knowledge of vocabulary are more proficient in language skills. Meara (1996) added that 'vocabulary competency contributes greatly to second language (L2) proficiency'. Vocabulary is the extent of one's knowledge of the meanings of words. It is one of the important parts of the English as Second Language (ESL) / English as Foreign Language (EFL) learning system for learners to be proficient in English.

\section{Computer Games and Language Learning}

Today, many approaches have been introduced to and taken by adult learners independently to gain more skills in and knowledge of English. The use of a computer as a learning tool has influenced many adults and, since the past century, it has become an important factor in learning language (Uberman, 1998). In this century, research on the potential of digital educational games in enhancing language learning has increased very fast from year to year. For example, perception towards learning via online games Muhamad Sabri, Sahrir and Nor Aziah (2011), learning English vocabulary (Nguyen \& Khuat, 2003), games and simulation (Akil, 2007), online vocabulary learning using games (Mohamad, 2011), language learning using video games (Lee, Cheon \& Key, 2008), and learning with digital games (Whitton, 2010). Computer games, for example, might be a suitable tool to improve English language as it provides language learning environment (Mich. et.al, 2004) .This is because, for playing the games, the users need to know basic English language in order to understand the instructions (Smith \& Mann, 2002) and, later, they will develop their knowledge of English as they play the games. Through a well-planned game, learners can practice different English skills, most importantly vocabulary. Furthermore, computer games can generate motivation and pleasure for learners as they are loaded with learning materials that learners can attempt (Chee Siang Ang \& Zaphiris, 2006) especially for learning the subjects and content that are most 
difficult to teach either they are dull or complicated (Prensky, 2001)

Since adult language learners have limited time and many responsibilities, they have restricted time to join language classes. Therefore, a self-study tool is needed to help adult learners (Ausburn, 2004). In this case, computer games might be an appropriate self-study tool as many of them can be used as learning tools, which might be of interest to young and adult learners. The language most used in the computer games on the market is English. Therefore, all game players need to learn English in order to continue playing the games correctly (Lee, 2008) and the learning will take place unconsciously.

Furthermore, when a computer game is used as a learning tool, it creates a different learning environment that is an independent learning (IL) atmosphere. According to Merriam and Caffarella (1999), many adult learners are self-directed learners, and they believe that computer games can give learners a self-directed and IL environment. Furthermore, computer games provide learners with the opportunity to practice grammar, vocabulary and writing, and motivate and encourage learners to interact and communicate in English. On the other hand, it can be utilized as a conceptual pedagogical model in the L2 learning domain. Learners will be exposed to formal and informal contexts of learning through the provision of a meaningful context for them to learn vocabulary (Gee, 2005). Besides, computer games evidently have been proved to be a learning motivational tool as they provide learners with opportunities to use English vocabulary in authentic activities.

\section{Computer Games and Independent Learning}

Independent learners (IL) is based on a philosophy developed in the 1970s and early 1980s (Holec, 1981) as a reaction to the traditional approaches stressing the mechanistic aspects of learning (Ranabahu \& Tamala, 2006) and it has gained enormous application in education in the late 20th and early 21 st centuries. The overwhelming demands of self-instruction, along with the shift in learning from teacher-centred to learner-centred, especially for adult learners, can affect learners' motivations. IL is a learner's self-reliance or independent ability to take responsibility for his/her own learning (Holec, 1981).

To be more motivated to achieve IL, learners need to develop three criteria; their self-confidence in making and acting upon their decisions, an appreciation of the value of reflecting on learning and the ability to take decisions about evaluating their learning approaches, whether what they have been doing turns out to be effective or whether they need to try another approach (Ranabahu \& Tamala, 2006). As adults have different responsibilities and limited time, they need some self-study tools to learn a language on their own without participating in language classes (Merriam, 2000). Besides, computer games and Digital Game-Based Learning (DGBL) might play the role of an appropriate self-study tool in the language learning process (Gee, 2005). Furthermore, computer games give learners the flexibility to learn at their own paces and from their own interests. Computer games also provide motivational tasks (Stephenson \& Rumley, 2005) that help sustain the learning effort as users are actively engaged in meaningful tasks. Besides, adult learners enjoy a great deal of control, freedom, and flexibility over what they learn while playing the game. If such theory applies for adult learners, it might make them independent learners (IL).

\section{Conceptual Framework}

The comprehensive conceptual framework of this study is based on the theories and works of researchers in cases involving the self-directed learning of adult learners (Garrison, 1997; Pilling-Cormick, 1997: Livingstone \& Sawchuk, 1999; Merriam, 2001), DGBL in L2 learning as a self-study tool (Warschauer \& Healey, 1998; Prensky, 2001; Gee, 2005) and an IL environment using self-study tools (Holec, 1981; Ranabahu \& Tamala, 2006). These theories are co-related to each other in a way that underlies the crucial perspectives of the self-directed learning of adult learners (Garrison, 1997; Pilling-Cormick, 1997; Livingstone \& Sawchuk, 1999; Merriam, 2001). Furthermore, as adult learners, their learning approaches are diverse; as they depend on their responsibilities and the time they spend on learning. In other words, they have limited time to attend classes to learn. In this case, self-study tools, such as computer games or DGBL, might be suitable for them. Besides, if the theories above apply, they might turn adult learners into independent learners. The diagram for this conceptual framework is as below: 


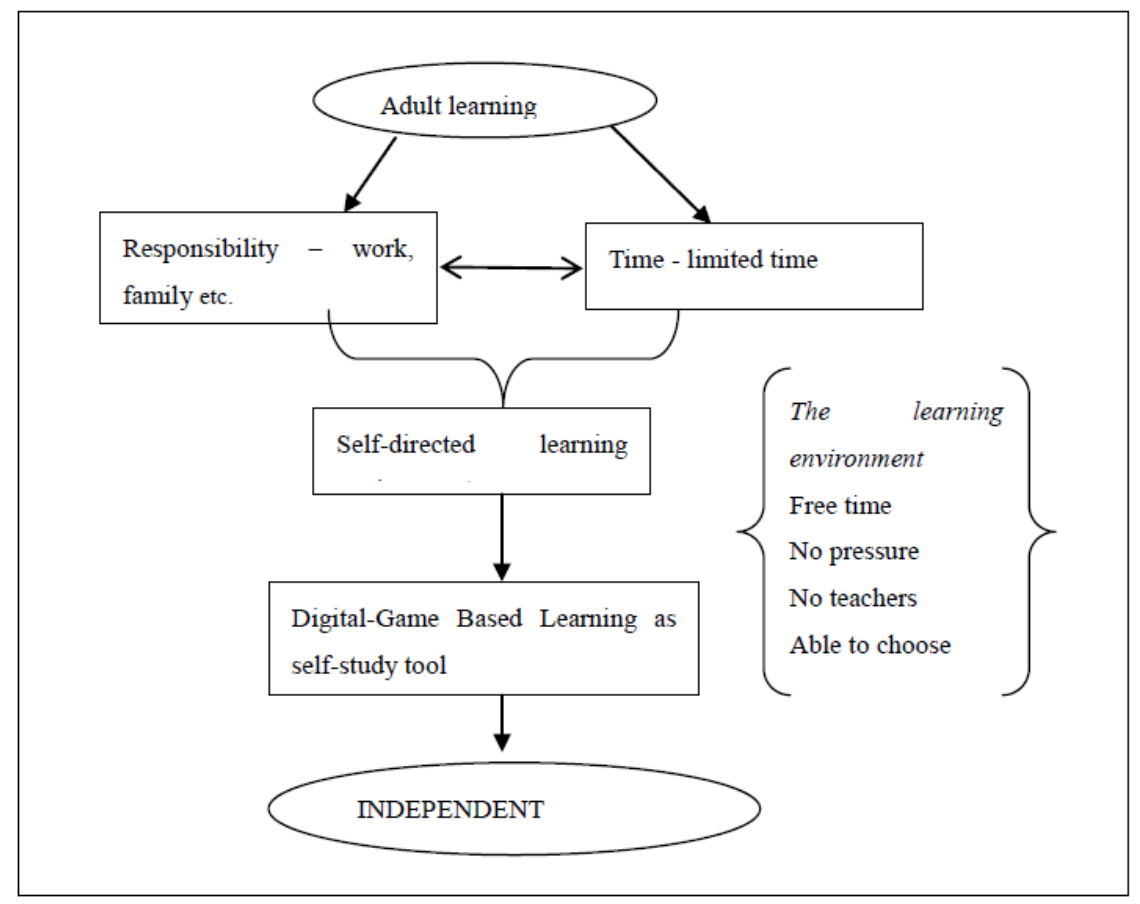

Figure 1. Conceptual framework

\section{Methodology}

The objective of this study is to explore how a computer game can be used as a learning tool and how the game can encourage adult learners to learn English vocabulary independently. A qualitative research method was used utilizing purposeful sampling to encourage volunteers to participate in the study. Three adult ESL learners, aged between 22 and 30 and with low English proficiency, were selected. The participants had MUET Band 2. (MUET is the Malaysian University English Test, an entry test for university; 6 is the highest score.) They were from different backgrounds; Participant A (PA) was a freshman working in a local restaurant; Participant B (PB) had a diploma certificate and intended to study further in a university; Participant C (PC) had a diploma certificate and worked as a salesman in a furniture shop. The participants used SIM 3 for two months. Below are the profiles of the participants. These participants were chosen based on voluntary, however they must be computer-literate and have computers connected to internet. In this study gender was not one of the criteria in choosing participants

\section{Participant A:}

A 25 year old freshman from one of the local universities in Malaysia studying biology. He has a computer at home and uses it for different purposes. He had limited experience with SIM 3, but he found it interesting. He took English classes from primary school to secondary school. After school, he stopped learning English due to his busy schedule. He believed he needed to improve his English because he needed to communicate with foreigners and travel abroad.

\section{Participant B:}

A 23 year old waiter. He has a diploma degree. He is interested in learning English because he wants to communicate with people. He has had no formal English classes since getting his degree. He learned English by watching English movies.

\section{Participant $C$ :}

A 29 year old man working as a salesman in his father's furniture shop. He realized that English is important after he received his diploma. He also indicated that he did not learn much English when he was in school because he was not interested in learning it. He is interested in online computer games. He believes that English is important in order to communicate with other people, especially in his line of work.

The instruments used for data collection were semi-structured interviews, observation, self-report check lists, pre- and post- vocabulary tests and vocabulary lists. Semi-structured interviews were conducted twice 
throughout the study. The purpose of interview was to understand their learning strategies, perceptions, attitudes and concerns about learning English in general, and learning vocabulary using the game. Observations were undertaken three times for each participant. The purpose of the observations was to understand how they learned vocabulary (if at all) and how the game helped them to use English vocabulary. The self-report check lists were given to students to complete every time they played the game, whereas the pre- and post-tests were to examine how much vocabulary learning had taken place while they played the game. The English words and phrases in the tests were chosen from the game SIM 3, which is the context of the study.

To test their vocabulary levels, the pre-test was given before the participants started the game and the post-test given after they had completed it. The pre-test and post-test consist of thirty multiple choice questions of vocabularies chosen randomly from the game which include nouns, verbs and adjectives. The participants had 30 minutes to answer the test. Pre-test was given before playing the game and post-test was given at the end of the study after they had played the game for two months. The results were compared to see the differences in their vocabulary-test scores.

Thematic analysis was used to identify themes immerging in the three major themes with sub-themes emerged from this study. The themes emerged are vocabulary learning, motivation and the IL environment.

\subsection{SIM 3 as Selected Gaming Platform}

The computer game selected for this study was SIM 3. It was chosen because it provides the language needed for this study and it is free online. The language used in all conversations and instructions in this game is English, and it is packed with English words in different meaningful contexts that create an authentic language-learning environment. Vocabularies in this game are relevant to different aspects of life which provides a good platform for learners to learn the meaning and uses different English words and phrases. Learners are exposed to different types of vocabularies in every level of the game. The game has different levels in which players need to complete one level before going to another level. Players can set their own learning goal and has no time limit to accomplish the goal. However, players need to plan the type of SIM environment they want to create as part of their goal. Players control their own Sim in activities and relationship in a similar manner to a real life.
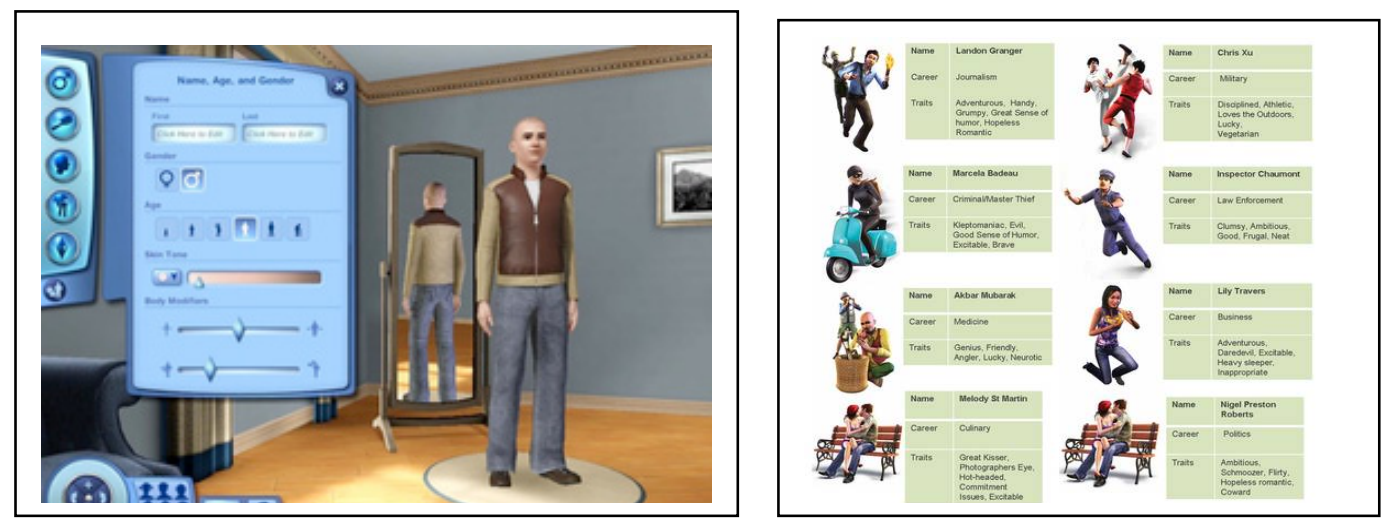

Figure 2. Screenshots of SIM3

The participants played SIM 3 for two months without any interruption; they were free to play the game at anytime and anywhere. In other words, they managed and organized their own game. There was no limitation on time or the number of games played at one time. They were allowed to set their own learning goals/game goals and to stop at any phase of the game. Learners were encouraged to learn as many new vocabularies as they desire without any restriction of syllabus because the main purpose was to learn the words unconsciously or automatically. Besides, they were also given the freedom to choose which game environment to participate in. From the beginning, they have the freedom to plan anything about their Sims characters such as gender, appearance, characteristics, personality, occupation, house, family, friends, and life they want in the game. The vocabularies learnt by the learners were depending on the type of game environment they have created. For example they learnt words related to characters for example if they chose appearance, they learnt vocabulary related to appearance. However, the flow of vocabulary learning and evaluation of the learning process will not be discussed in this paper. 


\section{Findings and Discussions}

\subsection{Summary of Findings}

Before going into detailed discussions on the findings, here is a summary of the data:

Table 1. Participants' involvement

\begin{tabular}{lclll}
\hline Participants & $\begin{array}{c}\text { English words } \\
\text { learned per playing } \\
\text { session }\end{array}$ & Learning strategy & Time spent playing & $\begin{array}{l}\text { Perceived learning } \\
\text { using the game }\end{array}$ \\
\hline $\begin{array}{l}\text { Participant A } \\
\text { (PA) }\end{array}$ & $5-7$ words & $\begin{array}{l}\text { Guess the meaning; } \\
\text { ask people nearby }\end{array}$ & $\begin{array}{l}\text { Three times per } \\
\text { week; } 1-2 \text { hours per } \\
\text { session }\end{array}$ & $\begin{array}{l}\text { Positive attitude; } \\
\text { learned 130 new } \\
\text { words }\end{array}$ \\
$\begin{array}{l}\text { Participant B } \\
\text { (PB) }\end{array}$ & 5 words & $\begin{array}{l}\text { Ask friends; look up } \\
\text { in online dictionary }\end{array}$ & $\begin{array}{l}\text { Three times per } \\
\text { week; } 1-2 \text { hours per } \\
\text { session }\end{array}$ & $\begin{array}{l}\text { Positive attitude; } \\
\text { learned } 100 \text { new } \\
\text { words }\end{array}$ \\
$\begin{array}{l}\text { Participant C } \\
\text { (PC) }\end{array}$ & $5-7$ words & $\begin{array}{l}\text { Used Google } \\
\text { Translation }\end{array}$ & $\begin{array}{l}\text { Three times a week; } \\
<>\text { hour per session }\end{array}$ & $\begin{array}{l}\text { Positive attitude; } \\
\text { learned } 120 \text { new } \\
\text { words }\end{array}$ \\
\hline
\end{tabular}

\subsection{Learners' Attitudes}

In general, learners have positive attitudes towards learning English using computer games. They enjoyed playing the game as they were able to create their own fantasy in the game. Student PB said:

"I could organized my programs and choose the best time to play and learn English vocabularies in the game while I have fun...no teacher, no rules, only me and the game.... i could have fun and learning at the same time..(PB11)

Besides that they also learned new vocabulary. On average 116.66 words were learned by each individual reported by the end of the study. The words indicated here were taken from the list of vocabularies that the learners kept throughout playing the game. All of them spent three times a week, about 2 hours per session playing the game. While playing the game, they also applied different types of learning strategies that suited them. This section will further discuss the findings based on the three major themes emerges from the study: vocabulary learning, motivation and IL environment.

\section{i. Vocabulary learning}

Generally, the vocabulary level of the three participants increased after using the computer game SIM 3 to practise their English. This was reflected in the overall improvements in their vocabularies test and their interests in playing the computer game SIM 3 as a self-study learning platform.

Table 2. Participants' test scores

\begin{tabular}{lllc}
\hline Participants & Pre-test & Post-test & Increased Marks \\
\hline PA & $53.33 \%$ & $86.66 \%$ & 33.33 \\
PB & $33.33 \%$ & $63.33 \%$ & 30.00 \\
PC & $53.33 \%$ & $76.66 \%$ & 23.33 \\
\hline
\end{tabular}

In addition, the flexibility of the game SIM 3 as a self-study tool and their goals to learn the English language motivated them to play more, which led them to learn more English vocabulary in the game. For example, PB commented:

I like learning English via computer games and learning English now is easier for me, because I am learning in a way that I am doing what I like and this motivated me to learn English (PB12)

Participant B further indicated that: 
It was not boring at all for me...(...) because I did not know a lot of things ...(...) At the end I will see what other new vocabulary I have learned and whether or not there is an improvement in my English (PB11)

The three participants also learned English vocabulary in a meaningful context. This computer game provides them with a learning environment that allows them to use the same words but in a different environment many times. Frequent and repeated contact with new English words in the game appeared to make learning vocabulary easier for them, as they had the chance to review what they had learned before. In other words, frequently exposing them to new words enables them to remember the meaning of the words. Therefore, English words will gradually accumulate as they play the game. The game also provides them with a learning environment that encourages learners to further understand the words by giving different situations using the same word. Not only do learners learn new words, but they are also able to remember and use them in real life situations (outside the game context).

For example participants said

... after some time playing the SIM, when the same words repeated in the game context in some special part of the game, then I remembered them. Therefore, after 2 or 3 sessions facing the same words in that special part of the game, I did not forget the meaning... (PA12)

...the first time it was difficult for me to understand the words...(...) then I looked for the meanings, then I got used to it and at the end somehow it became easy for me... (PB12)

The participants also acknowledged that their knowledge of English vocabulary has increased. This can be seen in their vocabulary lists. Each participant was asked, every time they played the game, to record all the new words that they had learned. From the list, PA recorded 130 new words, PB recorded 100 new words and PC recorded 110 new words. As reported by them in the interview, they learned some words related to creating SIM 3's personalities' appearances, job positions, and in communicating with other Sims in Sim City in every session they played the game.

Example of words recorded by participants:

PA: gender; pleasant; peaceful; equipment; body modifies; intimate; horizontal; etc

PB: dispute; military; astronaut; responsibility; distance; rotation; inventory; etc

PC: furniture; job opportunity; corridor; gardening; attention; book-work; distance etc

\section{ii. Motivation}

Motivation is the other factor that contributes to the effective learning of vocabulary in any learning environment Encountering new words in the game, which can be used outside the game, is one of the factors which motivated them to play the game as well as to learn English. PC indicated that the vocabulary he learned in the game can be applied outside the game.

...usually the words that I did not know related to furniture, were of most interest to me because I can use these words in my father's business in helping me to describe the furniture... PC12

Another important factor that motivated them to learn vocabulary was their aim in using English. Since they have jobs that needed them to use the language and the vocabulary used in the game can be used outside the learning environment, this encouraged and motivated them to play and to learn more new vocabulary related to their daily lives.

iii. Independent Learner (IL)

Another objective of this study is to investigate how the computer game SIM 3 encouraged participants to be independent learners. The data for this objective were taken from interviews.

The findings showed that the three participants enjoyed the freedom and control over what they did and what they learned. When asked about the freedom, all of them indicated that the lack of teacher control and the ability to learn without any restraint from the syllabus encouraged them to be independent. The ability to control the learner's own learning goals and leaning conditions will gradually increase the learner's self-confidence and self-management.

PB11 indicated that

I could organize my own programs and choose the best time to play and learn English vocabulary inside the game while having fun. There was no teacher, no rules, only me and the game. I believe that 
playing this game and learning at the same time is much better for me...I have little time to go to classes...(PB11).

PC, for example, explained that he could learn on his own without a teacher's help. This game uses flexibility of leaning, that is, no time limitation, no exam pressure, no teacher and no class rules but self-discipline in the learning processes, which made them feel independent and responsible for their own learning. They could manage their own time to learn English vocabulary. They had control over the game and the learning process as they could decide on how many words to learn, how to learn them and which learning strategies to use. They also had plenty of time with no stress or rules imposed on them since they were not tested. The three participants responded in the interview that they were satisfied with this type of learning which taught them to be independent learners. For example PC indicated that

\section{...I truly believe it provided me with independent learning and I could learn English through this game as I manage everything by myself. In this game it is you who decides what to build, what kind of life personality...(...) there is no time limit, what to learn, how to learn, and there is no mark and exam to be afraid of...this makes me comfortable and free to learn English and have fun...(..) it makes you feel independent..(PC12)}

From interview questions and the self-report check lists, all participants reported that the computer game SIM 3 can be useful as a self-study tool because it has the capacity to turn these adult learners into independent learners. Besides which, the most important attribute is that it also provides learners with a stress-free learning environment. In other words, for adult learners to be effective and productive learners they need to find out how to learn on their own, be critical thinkers and to experience different ways of becoming independent learners without any pressure from others.

\section{Conclusion}

The findings from this study show that computer games can be a tool for self-study and create an IL environment. Not only for those students able to learn on their own, but also for those motivated to learn. However, this situation will only occur when learners have set their own goals and purposes for learning. For example, PC's motive to learn English was to communicate with customers in his father's furniture shop and PB's motive was to communicate with different people because he is currently working in a restaurant that uses English with customers. Furthermore, learners are motivated to learn if they can apply the learning input in their daily lives. In addition, the informal stress-free learning environment provided by the computer game gives a meaningful learning experience to these adult learners that motivate them to learn (Stephenson \& Rumley, 2005). The learning experience they received in this type of learning environment gives great control, freedom and flexibility to adult learners which will develop them to be independent learners.

The findings show that adult learners in this study used various learning strategies according to their needs. However, the most frequent learning strategies used were guessing the meanings of the words based on the context, consulting people around them for the meanings of difficult words, and searching for meanings in online dictionaries. They also used vocabulary lists to note down difficult words and tried to remember the words by applying the words in different contexts in the game as they played.

This technique of vocabulary learning can be implemented as supplementary exercises to help low proficiency language learners to learn vocabulary in a fun learning environment. The learning environment that gives freedom to learners to choose what type of learning they needed is important to encourage learners to study independently. Furthermore, when there is no pressure from teachers, especially adult learners, they are able to learn on their own. It can be concluded that, ESL and EFL language learning needs to be supported with meaningful learning tools, for example computer games, so that learning can be more realistic and meaningful. ESL and EFL teachers can use computer games as self-study tools to make teaching and learning vocabulary more interesting, thus, enabling their learners to achieve successful vocabulary learning. Besides, learners also need to use learning strategies suitable to them to be able to learn vocabulary effectively. However, in order for adult learners to learn vocabulary, they need a tool that could develop their self-autonomy. Self-study tools, like computer games, can be used to help them learn independently. Another crucial point is that learners must have objectives for learning for the learning to take place. Learning without objectives can be meaningless.

\section{References}

Akil, G. K. (2007). Games and simulation: A new approach in Education. In D. Gibson, C. Aldrich, \& M. Prensky (Eds.), Games and Simulation In Online Learning, Research and Development Framework. USA : Information Science Publishing. 
Ang, C., \& Zaphiris, P. (2006). Computer Games and Language Learning. In T. Kidd, \& H. Song (Eds.), Handbook of Research on Instructional Systems and Technology (pp. 1-31). Hershey, PA: Information Science Reference.

Ausburn, L. J. (2004). Course design elements most valued by adult learners in blended online education environments: An American perspective. Educational Media International, 41(4), 327-337. http://dx.doi.org/10.1080/0952398042000314820

Barcoft, J. (2004). Effect of sentence writing on in L2 lexical acquisition. Second Language Research, 20(4), 303-334. http://dx.doi.org/10.1191/0267658304sr233oa

Garrison, D. R. (1997). Self-directed learning: Towards a comprehensive model. Adult Education Quarterly, 48(1), 18-33. http://dx.doi.org/10.1177/074171369704800103

Gee, J. P. (2005). Pleasure, learning, video games, and life: The projective stance. E-Learning, 2(3), 211-223. http://dx.doi.org/10.2304/elea.2005.2.3.2

Holec, H. (1981). Autonomy and Foreign Language Learning. Oxford: Pergamon.

Lee, S. K. (2008). Voices still in the margins: The need for literature texts by non-native speakers of English for the teaching of English. Educational Awakening: Journal of the Educational Sciences, 5(1), 1-14.

Lee, Y., Cheon, J., \& Key, S. (2008). Learners' perceptions of video games for second/foreign language learning. Proceedings of Society for Information Technology and Teacher Education International Conference, (1), 1733-1738.

Livingstone, D. W., \& Sawchuk, P. (Eds.). (1999). Working Class Learning, Final Report of the Working Class Learning Strategies Project. Toronto: OISE/UT.

Meara, P. (1996). The vocabulary knowledge framework, Linguistic Journal, San University. Retrieved November 20, 2012, from http://www.lognostics.co.uk/vlibrary/meara1996c.pdf

Merriam, S. (2000). Adult Learning and Development: Multicultural Stories. Malabar, FL: Krieger Publishing Company.

Merriam, S. B. (2001). Andragogy and self-directed learning: Pillars of adult learning theory. New Directions for Adult \& Continuing Education, 89, 3-14. http://dx.doi.org/10.1002/ace.3

Merriam, S. B., \& Caffarell, R. S. (1999). Learning in Adulthood. San Francisco, CA: Jossey-Bass Publisher.

Mich, O., Betta, E., \& Giuliani, D. (2004). PARLING. E-literature for supporting children learning English as a second language. Madeira, Funchal: Portugal.

Muhammad Sabri, S., \& Nor Aziah, A. (2011). A study on Malaysian language learners' perception towards learning Arabic via online games. GEMA Online Journal of Language Studies, 11(3), 129-145.

Nguyen, T. T. H., \& Khuat, T. T. N. (2003). Learning vocabulary through games: The Effective of learning vocabulary through games. Asian EFL Journal. Second Language Acquisition Theory Journal. Retrieved May 12, 2012, from http://asian-efl-journal.com/dec_03_sub.Vn.php

Pilling-Cormick, J. (1997). New directions for adult and continuing education. Transformative and Self-Directed Learning in Practice, (74), 69-77.

Prensky, M. (2001). Digital Game-based Learning. New York, NY: McGraw-Hill.

Ranabahu, S., \& Tamala, M. (2006). Evaluating Independent Learning: the impossible dream. 19th Annual EA Education Conference. Monash University English Language Center.

Sahrir, M. S. (2011). Formative evaluation of an Arabic online vocabulary learning games prototype: Lesson from a Malaysian higher learning institution experience. In N. Alias, \& S. Hashim (Eds.), Instructional Technology Research, Design and DevelopmentL Lessons from the Field IGI Global. Hershey, PA: United States. http://dx.doi.org/10.4018/978-1-61350-198-6.ch022

Smith, L., \& Mann, S. (2002) Playing the gameness in interactive game based learning. Proceedings of the $15^{\text {th }}$ Annual NZCCQ, 2002: 397- 402. Hamilton, New Zealand.

Stephenson, P., \& Rumley, G. (2005). Inclusive work at a European level: A case study. Support for Learning, 20(3), 141-145. http://dx.doi.org/10.1111/j.0268-2141.2005.00378.x

Uberman, A. (1998). The use of games for vocabulary presentation and revision. Forum, 36(1), 20-27. Retrieved August 1, 2011, from http://exchanges.state.gov/forum/vols/vol36/no1/p20.htm

Warschauer, M., \& Healey, D. (1998). Computers and language learning: An overview. Language Teaching Forum, 31, 57-71. http://dx.doi.org/10.1017/S0261444800012970

Whitton, N. (2010). Learning with digital games: A practical guide to engaging students in Higher Education. London: Routledge. 